\title{
The Role of Civics Education in Enhancing Civic Virtues of Students: The Case of Wollo University; Ethiopia
}

\author{
Aliyou Wudu \\ Department of Civics and Ethical Studies, Wollo University, Dessie, Ethiopia \\ Email address: \\ aliyouwudu@gmail.com \\ To cite this article: \\ Aliyou Wudu. The Role of Civics Education in Enhancing Civic Virtues of Students: The Case of Wollo University; Ethiopia. International \\ Journal of Secondary Education. Vol. 8, No. 1, 2020, pp. 1-5. doi: 10.11648/j.ijsedu.20200801.11
}

Received: September 18, 2019; Accepted: October 31, 2019; Published: April 28, 2020

\begin{abstract}
The general objective of the study was to explore the practical benefits of civics and ethics course in changing the behavior and attitudes of university students and thereby contributing to the development of civic virtues. The study employed qualitative data gathering techniques such as personal interviews and qualitative content or document analysis. A total of 25 students union members, department and college heads, university security officials, heads of University Ethics and Anticorruption directorate, heads of Student Services, and members of top management were participated in the study. They were chosen using purposive sampling techniques. The findings indicate that due to the teaching of civics and ethics, the knowledge of students have been improved. Howevr, students exercise their freedom and rights with out fulfilling their obligations. The university focus on providing too much rights for students. The student union, Feedback clubs and representatives of students do little to improve the behavior of students. Some students are not polite and punctual. Students respect the diversity among ethnic and religious groups. Lack of role models of in the part of instructors; the commitment and attention of the top leaders is not adequate; students are exposed to various drugs such as chat and alcoholism; there is low national feeling and vision; and Civics teachers are not interested to teach the course. The study recommend that use media, films and posters to raise the awareness of students about the national feeling; revise the civics and ethics curriculum by scholars and who are politically independent; history and geography courses should be taught as a common course for all students; instructors should give more attention to teach ethical values and principles and focus on duties and responsibilities; counseling and advice services should be provided for students; and legal measures should be taken by the university.
\end{abstract}

Keywords: Civic Education, Citizenship, Civic Virtue, Participation, Diversity, Tolerance

\section{Introduction}

Civics and Ethical education is a wide field of discipline that includes a wide range of philosophical, political and ideological perspectives, and of pedagogical approaches, goals and practices. There is a general consensus that the main purpose of citizenship education is the development of good democratic citizens. Citizenship education can be used as a tool for maintaining the status quo, but also for empowering individuals and groups to struggle for change [1]. Civic education promotes self-rule and just rule. In nondemocratic political systems, civic education aims at promoting obedience to the state while promoting ideological indoctrination. In Ancient Greece city-states, the goal of civic education was the inculcation of civic virtue- meaning the individual's devotion to the public good over his private good.
This goal required teaching every part of the individual's character and intellect [2].

Civics and Ethical education should be primarily concerned with emancipation, which implies the development of active, informed and critical citizens who can participate effectively in civic life and in the affairs of the state. Citizenship education should examine gender, race and class structures, promote social justice and diversity, and prepare citizens for inclusive political processes of deliberation and decision-making. Good citizens are conceptualized as compassionate, politically engaged, concerned for social justice and the environment, tolerant of others, willing and able to dialogue, and active participants in public life change. Citizenship education in all democratic societies should help students examine issues and questions related to major social categories such as race, class, ethnicity, 
religion, gender, language, and disability $[1,3]$.

Civics and Ethical education for the twenty-first century should help to build a culture of peace. Today, it is urgent for Civics and Ethical education to advance pedagogical strategies to promote cooperation, dialogue, and a sustainable peace that is based on justice. It is obvious that Civics and Ethical education alone cannot bring peace to our planet, yet it can make a valuable contribution to create the subjective conditions for more peaceful situations. This includes the development of competencies for peacemaking, conflict resolution, healing, reconciliation and reconstruction. It also includes an understanding of Gandhian-based nonviolent civil disobedience philosophies, strategies and skills. A peace-oriented citizenship education can foster the development of values, attitudes and skills to nurture peace within ourselves and in our personal relationships and to create the conditions for peace in our own communities and in the global community [1].

A possible strategy to start this would be to connect schools with other agencies and organizations like museums, libraries, neighborhood associations, social clubs, community gardens, universities, cooperatives, community centers, political representatives, local media, arts and crafts clubs, and the like. Learning communities would work through reciprocal networks than through hierarchical, bureaucratic institutions, and schools could play a particularly dynamic role in igniting and maintaining those relationships. Learning communities could complement this purpose by constituting new pedagogical and democratic spaces for schools, other institutions and surrounding communities to come together, share their knowledge, learn collectively, and promote local development and democratic governance [1].

Civic virtue is desirable in our journey of nation-building. Furthermore, Civics and ethical studies could play an important role in addressing one of the fundamental challenges of nation-building in the Federal Democratic Republic of Ethiopia (FDRE). "The education and training policy envisages bringing-up citizens endowed with humane outlook, countrywide responsibility and democratic values having developed the necessary productive, creative and appreciative capacity in order to participate fruitfully in development and the utilization of resources and the environment at large" [4].

One of the general objectives of the Education and Training Policy of the FDRE has been to bring up citizens who respect human rights, stand for the well-being of people, as well as for equality, justice and peace, endowed with democratic culture and discipline. Some of the specific objectives include, inter alia, to provide education that promotes democratic culture, tolerance and peaceful resolutions of differences and that raises the sense of discharging societal responsibility and to provide education that can produce citizens who stand for democratic unity, liberty, equality, dignity and justice, and who are endowed with moral values (Ibid). The role of civics and ethics in inculcating civic virtue in the minds of university students can be learned from other countries in the world which use civics and ethics education for changing the behavior and attitudes of citizens. It is also possible to believe that teaching civics and ethical education to students and the society could be taken as an opportunity in our effort towards democratization, peace and nation-building project. For this to happen, educational institutions should be at the forefront in teaching civics and ethics to their students.

According to a document (Amharic Version) prepared by the Ethiopian Government for discussion in the public higher institutions showed that teaching civics and ethical education in the country failed to bring the expected impact on the behavior of students. The same document also mentioned a number of limitations in the teaching and learning process in civics and ethics course [5].

Promoting human dignity, stability and economic development needs the strengthening of democratic values within the society. However, achieving these valuable objectives necessitates the identification and analysis of the main constraints that a nation faces [6]. Since 1991, the Federal Democratic Republic of Ethiopia (FDRE) has given considerable attention to promote and protect human rights and democracy through the instrumentality of teaching Civics and Ethical Studies for students at all levels of schools including higher institutions. But, various studies showed that the success stories are not good as it is expected. According to the study, there are numerous challenges faced in terms of achieving the expected results. These challenges require, among others, designing and implementing the mechanism to integrate civics and ethics into the day-to-day lives of citizens in general and students in particular [5].

Therefore, the main motive of this research is to analyze the contribution of teaching civics and ethical study courses in practically improving students' civic virtues in the sample university.

The main objective of this study is to analyze the contribution of civics and ethical education in developing civic virtues of university students in Wollo University. The specific objectives include to:

1) Assess the practical benefits of civics and ethical education in developing students civic virtues;

2) Analyze the role of stakeholders in developing civic virtues of students, and

3) Identify challenges faced in the teaching and learning process of civics and ethical education in the sample universitya

\section{Methods}

\subsection{Design and Approaches}

This study mainly used explanatory research design. The study is qualitative in its approach. A number of secondary sources such as the Education Policy of the Federal Democratic Republic of Ethiopia (FDRE), the Civics and Ethics Curriculum and the relevant university legislations were consulted to understand the wider policy objectives of teaching civics and Ethics education in post-1991 Ethiopia. 
This study excludes primary and secondary students and students of the Institute of Technology Kombolcha campus. Hence, second year and above students who are currently learning in the university and took civics and Ethical Study courses were purposively selected. In addition, interviews were conducted with members of the Student Union, heads of colleges, Security officials, and members of top management, Ethics and Anti-corruptions Directorate Director and Director of Students Service.

Table 1. Sample population and Sample Size for Interview.

\begin{tabular}{llll}
\hline Name of the College/Institution & No. of Departments & Sample Departments & Sample size \\
\hline College of Humanities and Social Sciences & 10 & 5 & 2 \\
College of Business and Economics & 5 & 3 & 2 \\
College of Agriculture & 6 & 4 & 3 \\
College of Natural Sciences & 8 & 1 & 4 \\
College of Teachers Education and Behavioral Sciences & 2 & 1 & 1 \\
School of Law & 1 & 1 & 1 \\
School of Veterinary Medicine & 1 & 8 & 2 \\
College of Health Sciences & 16 & 25 \\
Total & 49 & 25 \\
\hline
\end{tabular}

Source: Wollo University Main Registrar, 2018

\subsection{Data Collection Techniques}

Both primary and secondary sources of data were used to collect data. In order to analyze the views of respondents on the significances of learning civics and ethical study in the university in promoting civic virtues, and the practical challenges faced.

In addition to questionnaire which were self-administered by students, a key informant, semi-structured open-ended questions were prepared for interviews to be conducted with selected second year and above students, the leaders of Student Unions, Heads of Colleges and departments, members of top management and teachers of Civics and Ethical Study. A non-probabilistic purposeful sampling technique were used to choose interviewees because they know the most about the subject under investigation. The interviwees are believed to provide the needed information for the study [7]. Besides, other secondary documents such as the Civics and Ethical study curriculum, Education and Training Policy of the Federal democratic republic of Ethiopia and other relevant sources will be consulted.

\subsection{Data Analysis}

The process of data analysis and interpretation involves creative insight and careful attention to the purpose of the study. Analysis and interpretation are separate processes. Analysis is the process of "bringing order to and organizing data into patterns, categories and basic descriptive units". Interpretation, on the other hand, involves attaching meaning and significance to the analysis, explaining descriptive patterns and looking for relationships and linkages among descriptive dimensions (Ming Zhang, 2002). Therefore, the data collected on the basis of the information gathered through secondary sources were organized, edited, processed, and analyzed thematically. The qualitative data gathered from interviews were analyzed by their content.

\section{Results and Discussion}

As it has been pointed out above, this study has the general objective of assessing the contribution of civics and ethical education in developing civic virtues of university students in Wollo University. In order to attain this general objective, the specific objectives are to (1) Assess the views of respondents on the practical benefits of civics and ethical education in developing civic virtues; and (2) Analyze the critical challenges of teaching and learning civics and ethical education in the sample university.

In order to address the objectives mentioned above, interview guide was designed for college and department heads and members of the top management, including the university president, vice president of administration, Director for Ethics and Anti-corruption Directorate, Security Directorate Director and Student Affairs Directorate Director. The first question asked were" How do you view the practical role of civic and ethical study course in developing a student's civic-attitude or civic virtue"?. The answer for this question was both positive and negative. Some respondents believe that due to civic and ethical study course provided for students there have been encouraging results in the university. For example, there has been an improvement in student's consciousness and knowledge of stu. Particularly, the major change was related to an improved understanding of rights.

There is too much focus to the exercise of students' rights than duties, responsibilities and obligations. According to some respondents" the university provided too much freedom and rights for students." To substantiate this argument, respondents indicated that the dressing style and the manner of students did not show improvements. Furthermore, the Student Union, Feedback clubs and representative of students are not focused on changing the behavior and attitude of students. On the contrary few respondents argued that" Nothing has been changed." This group of respondents said that students are not polite and punctual. There is still less tolerance of diversity in the university. Therefore, this group of respondents said that teaching civic and ethics course failed to bring the expected change of attitude of students in the university.

Participants were asked to explain their role in enhancing 
civic virtues of students. Almost all respondents revealed that they have tried to support students, give them advice and tried to be a good model for students. There have been formal and informal discussions and meetings to improve students' behavior. Respondents were also asked about extracurricular activities designed and practiced in the university. According to the information, there are some opportunities available for students to practice the theories learned in the classroom. For example, there are different opportunities to participate such as Peace Forum, Anti-Corruption Club, Human right club, English clubs and student union in the university. However, the practical contribution of these various platforms to the improvements of civic attitudes of students is not satisfactory. Even some respondents said that the university failed to create the necessary opportunity for students. The main reasons for the weak performance of the different forums are "lack of top leadership commitment and failure to practice the university legislation".

Leaders of Student Union of Wollo University were asked a number of questions. To understand their level of knowledge they were asked to define the concept of civic virtue. Most of them replied that civic virtue is about the goodness and character of everybody. It is also about fulfilling obligations and the moral excellence of an individual. Respondents listed some examples of civic virtue such as loyalty, open-mindedness, positive attitude, and understanding duties and responsibilities.

Leaders of student union were asked about the benefits of civic and ethics course in positively changing students' attitude. Almost all respondents agree that students have benefited a lot from the civic and ethic course. For example, students' behavior has been positively changed and students improve their social interaction with others. Students tolerance and acceptance of diversity is also improved due to the civic and ethic course. According to some leaders of the student union, they have the opportunity to participate in various clubs in the university and involve in different training opportunities provided by the university such as life skill and entrepreneurial skill development trainings.

Leaders of the student union were asked their view about the support provided by the university to address different problems. Some respondents said that the university is providing the necessary support to the demands of the students. For example, students get relative peace in the campus. However, others argued that the university does not fully responding to their demands and students are not satisfied. According to leaders of the student union, the following are the critical challenges related to the civic and ethics course. These are;

1) Some teachers teach their personal political opinion and due to these students are confused;

2) There is a lack of adequate teaching material about the course; and

3) Lack of awareness of students about the benefits of the course

Due to these, there are a number of disciplinary problems made by the university students such as religious related problems; regional and identity based conflicts, theft, students are organized based on language, religion, tribes, ethnic groups, etc. There are major problems created around the students' cafeteria, library, sport fields, classrooms and dormitory areas in the university.

Another group of participants in the study were civics and ethic instructors of Wollo University. They were asked a total of 24 close-end questions in the form of "yes", "No" and "Not Sure". The questions and answers provided by instructors are discussed below. Respondents were requested to explain their opinion about the major disciplinary problems and challenges faced regarding the behavior of students and instructors. The main common challenges faced ine the university were mentioned by respondents.

The have been more focus on civics than ethics and morality which led to unethical behavior of both students. According to the response of participants, some instructors are not willing to teach specific chapters to students. There is a lack of role models of in the part of instructors. The commitment and attention of the top leaders of the university is not adequate. Students and some department heads view civic and ethics course as "common course" and give less attention. The study also found that some students are exposed to various drugs such as chat and alcoholism.

There is low national feeling and vision among the students and there is a tendency to benefit in a shortcut way. Respondents said that some civics instructors are not knowldgable in the field and have less interest to teach the course. There is high prevalence of cheating, theft and drunkenness on the part of students. Less respect of students to their teachers. There are recurrent conflicts and disagreement among civic teachers in the university.

\section{Conclusion}

Recently, Ethiopians have been witnessing worrying trends of mutual conflicts among brothers and sisters in various parts of our country. Universities are not immune from this situation. Some of the negative consequences of these seemingly "ethnic" and "border" conflicts remind us that strengthening national, regional and local democratic institutions focus on student's democratic and ethical behavior should be at the top of the country's policy priority. There is a need increase for a political will and leadership commitment from all stakeholders before we reach to a point of no return. Particularly, there is a need to deepen the understanding of our students through teaching civics and ethics. This should be at the heart of the day to day activity of higher Education institutions in particular and other stakeholders in general.

Although Ethiopia has registered commendable achievements in strengthening the culture of democracy, tolerance and dialogue in the past 27 years, the researcher of this study believe that there remained a lot to be done.

The findings indicate that due to the teaching of civics and ethics, the knowledge of students have been improved. Howevr, students exercise their freedom and rights with out 
fulfilling their obligations. The university focus on providing too much rights for students. The student union, Feedback clubs and representatives of students do little to improve the behavior of students. Some students are not polite and punctual. Students respect the diversity among ethnic and religious groups. Lack of role models of in the part of instructors; the commitment and attention of the top leaders is not adequate; students are exposed to various drugs such as chat and alcoholism; there is low national feeling and vision; and Civics teachers are not interested to teach the course;

\section{Recommendation}

The findings of this study show that there are still huge cliffs between the expectation of the students, university leaders and civics instructors. In order to address the main problems mentioned, respondents were asked to give their view on how to tackle the challenges. The following are the main solutions forwarded by respondents. These are:

i. Use media, films and posters to raise the awareness of students about the national feeling;

ii. Revise the civics and ethics curriculum by scholars who are politically independent;

iii. History and geography courses should be taught as a common course for all students;

iv. Instructors should give more attention to teach ethical values and principles and focus on duties and responsibilities;

v. Counseling and advice services should be provided for students;

vi. Legal and disciplinary measures should be taken against students who deliberately violete the rules of the university;

vii. Additional training should be given to both students and teachers on the subject;

viii. Other university staff members should take training about civics and ethics so that they could play their own constructive roles;

ix. More focus should be given to teach children about tolence, diversity, critical thinking and civic virtue at lower level grades;

x. Top management of the university should give the necessary support and follow-up to improve the awareness of students;

\section{References}

[1] Schgurensky, D. and John P, Mayers (2003), Citizenship Education: Theory, research and Practice. Encounters on Education; Volume 4, Fall 2003 pp. 1 - 10

[2] Ceaser, J. (2013), The Role of Political Science and Political Scientists in Civic Education.

[3] James, A., chary, A., carlos, E., carole, L., Merry, M., kogila, A., Stephen, O., caryn, P., and walter, C. (2018), Democracy, and Diversity: Principles and Concepts for Educating Citizens in a Global Age. Center for Multicultural Education. Accessed from http:// www. DemDiv pdf. On February, 2018.

[4] Federal Democratic Republic of Ethiopia (1994), Education and Training Policy. St. George Printing Press.

[5] Federal Democratic Republic of Ethiopia (2010), Growth and Transformation Plan II (GTP II) (2015/16-2019/20). Volume I: Main Text. Addis Ababa, Ethiopia.

[6] Fetene, B. (2017), The Role of Civics and Ethical Education in Shaping Attitudes of Students: The case of Jimma College Teachers Education. Vol 17 (2); Global Journal Inc., USA.

[7] Kumar, R. (2011), Research Methodology: A step-By-Step Guide for Beginners. $3^{\text {rd }}$ Edition, SAGE Publication; London.

[8] Endalcachew, B. (2016), Role of Civics and Ethical Education for Development of Democratic Governance in Ethiopia: Achievements and Challenges. Journal of Pacific Review B: Humanities and Social Sciences. 